\title{
Application of an airborne hyper-spectral survey system CASI/SASI in the gold-silver-lead-zinc ore district of Huaniushan, Gansu, China
}

\author{
Yuhai Fan ${ }^{1,2,3, \star}$, Yuqing Wan², Hui Wang ${ }^{2}$, Xingke Yang ${ }^{1}$, Min Liang ${ }^{2}$,Chunjuan Pan ${ }^{2}$, \\ Shaopeng Zhang ${ }^{1,2}$, Wenbo Wang ${ }^{2}$ And Furong Tan ${ }^{2}$

\footnotetext{
${ }^{1}$ Chang'an University, School of Earth Science and Land and Resources, Xi'an, 710054 China; (*corresponding author: 170269854@qq.com)

${ }^{2}$ Geological Exploration Institute of Aerial Photogrammetry and Remote Sensing Bureau, Xi'an, 710199 China
} \\ ${ }^{3}$ Yulin University, School of Management, Yulin, 719000 China
}

doi: $10.4154 / g c .2021 .04$

Article history:

Manuscript received May 09, 2019 Revised manuscript accepted February 03, 2021 Available online February 28, 2021

Keywords: Airborne hyper-spectral survey system CASI/SASI, Huaniushan gold-silver-lead-zinc ore district, hyperspectral-alteration mineral mapping of wall rock, mineralized-alteration-zone hyperspectral identification

\begin{abstract}
The airborne hyper-spectral survey system CASI/SASI, which has an integrated system for gathering both image an spectral data, is at the cutting edge developments in the remote-sensing field. It can be used to directly identify surface objects based on diagnostic spectral characteristics. In this paper, the CASI/SASI were used in the Huaniushan gold-silver-lead-zinc ore district-Gansu to produce a lithologic map, identify altered minerals, and map the mineralized-alteration zones. Radiometric correction, radiometric calibration, atmospheric correction (spectral reconstruction), and geometric corrections were carried out in ENVI to pre-process the measured data. A FieldSpec ${ }^{\circledR}$ Pro FR portable spectrometer was used to obtain the spectral signatures of all types of rock samples, ore deposits, and mineralized-alteration zones. We extracted and analyzed the spectral characteristics of typical alteration minerals. On the basis of hyper-spectral data, ground-spectral data processing, and comparative analysis of the measured image spectrum, we used the spectral-angle-mapping (SAM) and mixture-tuned matchedfiltering (MTMF) methods to perform hyperspectral-alteration mineral mapping of wall rock and mineralized-alteration-zone hyperspectral identification. Hyperspectral-remote-sensing geological-classification maps were produced as well as distribution maps of all kinds of alteration minerals and mineralized-alteration zones. Based on geological comprehensive analysis and field investigations, the range of mineral alteration was proven to be the same as shown by the remote-sensing imagery. Indications are that airborne hyperspectral-remote-sensing-image CASI/SASI offer good application results and show a promising potential as a tool in geological investigations. The results will provide the basis for hyperspectral remote-sensing prospecting in the same or similar unexplored areas.
\end{abstract}

\section{INTRODUCTION}

Due to its wide coverage, easy accessibility, and high economic efficiency, remote-sensing imagery has been broadly applied to dynamic monitoring of land use, agricultural surveying (LIU et al., 2017; XIE et al., 2017; JIANG et al., 2018; HOWARI et al., 2019), urban-survey planning (WANG et al., 2016; SUN et al., 2017; HU et al., 2018), mineral-resource development (FAN et al., 2021), environmental monitoring and investigation (WANG et al., 2018; MING et al., 2018; ALIJAGIĆ \& ŠAJN, 2020), basic geological and resource surveying (SHI et al., 2017; XIE et al., 2020), geological disaster and emergency investigation (GUO et al., 2009; ZHOU et al., 2017; WEI et al., 2017), geological-hazard monitoring, and emergency investigation (ZHAO et al., 2017; ZHONG et al., 2018). With continuous development and progress of sensor and computer technology, multispectral remote-sensing imagery has developed from low-medium to high spatial, spectral, and radiation resolution. Remote-sensing images have great potential for natural-resources surveys.

Hyperspectral remote sensing is a technology by which image data are divided into many very narrow and continuous spectral datasets to detect the visible, near infrared, mid-infrared, and thermal-infrared bands of the electromagnetic spectrum (HUNT, 1989; CLARK et al., 1990; PU \& GONG, 2000; TONG et al.,
2006), thereby offering a high spectral resolution. Many unrecognized substances in wide-band remote sensing can be detected in the hyperspectral data and quantitatively studied (CLARK et al., 2003; TANG et al., 2006; SCHAEPMAN et al., 2009; KRUSE, 2012; VAN DER MEER et al., 2012). Because various minerals and rocks have diagnostic spectral-characteristic-absorption bands in the range of 400-2,500 $\mathrm{nm}$, hyperspectral remote sensing can better capture the characteristics of minerals. Based on these characteristic spectral features, mineral compositional information can be inverted and identified. Thus, classification, mapping of rocks and mineral-resource exploration can be performed (CLARK et al., 2003; GAN \& WANG, 2007; ZHANG et al., 2011; WEI et al., 2017).

Since the mid-1980s, with the rapid development of key technologies such as data acquisition, radiation calibration, spectral reconstruction, and data processing, many applications of hyperspectral remote-sensing technology to the fields of geology and mineral resources have been performed by researchers around the world, resulting in some noteworthy new achievements (HUNT, 1989; CLARK et al., 1990, 2003; PIETERS \& MUSTARD, 1988; KRUSE et al., 1990; CLOUDS, 1996; YESSY et al., 2011; LIU et al., 1999; GAN et al., 2000; WANG et al., 2000; YAN et al., 2004; WANG et al., 2010). At 
present, hyperspectral data are playing an increasingly important role in rock and mineral identification (DRAKE, 1995; BISHOP et al., 2011; POUR et al., 2013), archaeology (CHEN et al., 2017), solid-mineral and oil and gas exploration (GUO et al., 2012; WANG et al., 2007; HU et al., 2009; ZHOU, 2014), environmental protection and monitoring (ZHAO et al., 2013; EVERITT et al., 1988; TRENC et al.,1999; WAN et al., 2003; HOWARI et al., 2019), vegetation classification and detection (LI et al., 2014), and lunar and planetary exploration (BANDFIELD, 2002; LAPOTRE et al., 2017), among others.

Here, the CASI/SASI data were used in the Huaniushan gold-silver-lead-zinc ore district-Gansu to produce a lithologic map, identify altered minerals, and map the mineralizedalteration zones. A FieldSpec $\AA$ Pro FR portable spectrometer was used to obtain the spectral signatures of all types of samples for rock, ore deposits, and mineralized-alteration zones. The spectral characteristics of typical minerals related to gold-silver-lead-zinc ore were extracted and analysed. Combined with worldview-2 high-resolution satellite remote sensing images and geological data, the remote sensing geological work of gold, silver, lead and zinc deposits in this area was carried out. Finally, hyperspectral-alteration mineral mapping of wall rock and hyperspectral identification of mineralizedalteration zones were performed in the study area, and their effects were verified by field investigation. These results will provide the basis for hyperspectral remote-sensing prospecting in the same or similar unexplored areas.

\section{GEOLOGICAL FRAMEWORK}

The gold, silver, lead and zinc metallogenic region of Huaniushan is located in Beishan, Gansu Province. Since the 1950s, the gold and silver deposit of Huaxishan, tungsten-molybdenum deposits of Huadongtan, the molybdenum deposit of Huaheitan, gold deposit of Huaniushan, copper-iron-tin deposit of Huaxitan, and silver-gold deposit of Nanquan have been discovered one after another, such that the area is now recognized as one with a concentration of noble and rare metals (NIE et al., 2002; XI'AN INSTITUTE OF GEOLOGY AND MINERAL RESOURCES, 2006). The Huaniushan-Heishan-Shuangyingshan rift belt was a site of geotectonic activity in the early Palaeozoic, belonging to the northern margin of the Dunhuang massif active belt of the Beishan Tarim plate (CAO et al., 2008; DAI, 2010). The main strata exposed in the mining area belong to the Pingtoushan Formation of the Upper Jixian System, which can be further divided into three lithologic segments: $\mathrm{Jx}_{3}{ }_{3}{ }^{\mathrm{C}}, \mathrm{Jx} p_{3}{ }^{\mathrm{b}}, \mathrm{Jx} p_{3}{ }^{\mathrm{a}}$. It is a set of shallow-sea facies shallow metamorphic clastic rock-carbonate rock-basic-intermediate volcanic rocks formation. It is the main ore-hosting horizon in the area (YANG et al., 2010) (Figure 1).

The faults in the mining area trend mainly EW, NW, NE and $\mathrm{SN}$, with a scale that extends from hundreds to thousands of metres. The broken bandwidth is several metres to tens of metres. Rocks on both sides of the fault zone are broken. Mylonite, fault breccia and fault scratches occur in the fault zone. The fault shows the characteristics of multi-stage activity (DAI, 2010). The folds are mainly E-W trending complex-fold structures, with N-S, NE-SW, and NW-SE trending small-scale secondary folds superimposed at a later stage. Magmatic activity was obviously controlled by E-W- trending and NW-SE trending tectonic belts. Emplacement took place during the Variscan and Indosinian epochs (HE et al., 2012). Influenced by multiple magmatic intrusions and hydrothermal activities, the rocks underwent relatively strong alterations (diopside-tremolite, skarnization, uralitization, zoisitization, and sericitization, etc.) (DAI, 2010; YANG et al., 2010).

\section{METHODS}

Here, the CASI/SASI data were used as the main information source to carry out remote sensing geological work on gold, sil-

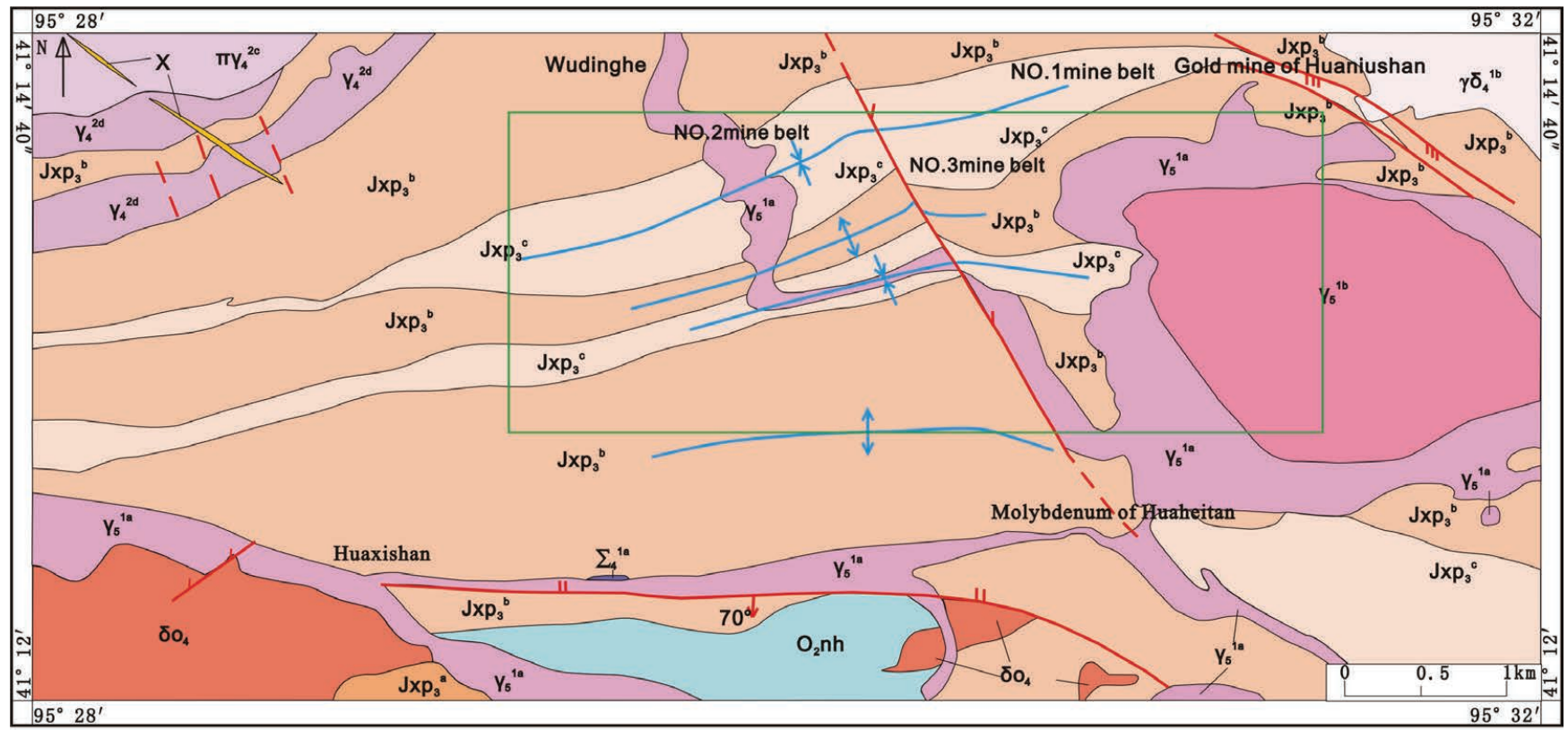

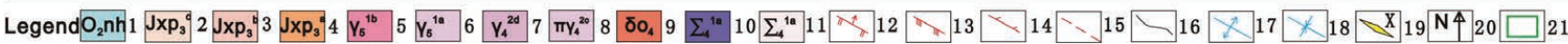

Figure 1. Geological map of the Huaniushan gold-silver-lead-zinc ore district (1. HuaniushanGroup in Middle Ordovician; 2. Third member of the Pingtoushan Formation of the Jixian System; 3. Second member of the Pingtoushan Formation of Jixian System; 4 . The first member of the Pingtoushan Formation of the Jixian System; 5. The second-stage granite of the Indosinian Period; 6 . The first-stage granite of the Indosinian Period; 7. The granite of the Middle Variscan period; 8. Porphyry granite of the Middle Variscan period; 9 . Quartz diorite of the Middle Variscan period; 10. Altered peridotite of the Early Variscan period; 11. Granodiorite of the Early Variscan period; 12. Reverse faults; 13 . Compressive-torsional faults; 14 . Torsional faults; 15 . Faults of unknown nature; 16. Stratigraphic boundary; 17. Anticline; 18. Syncline; 19. Lamprophyre veins; 20. North finger; 21. Coverage area of hyperspectral data). 


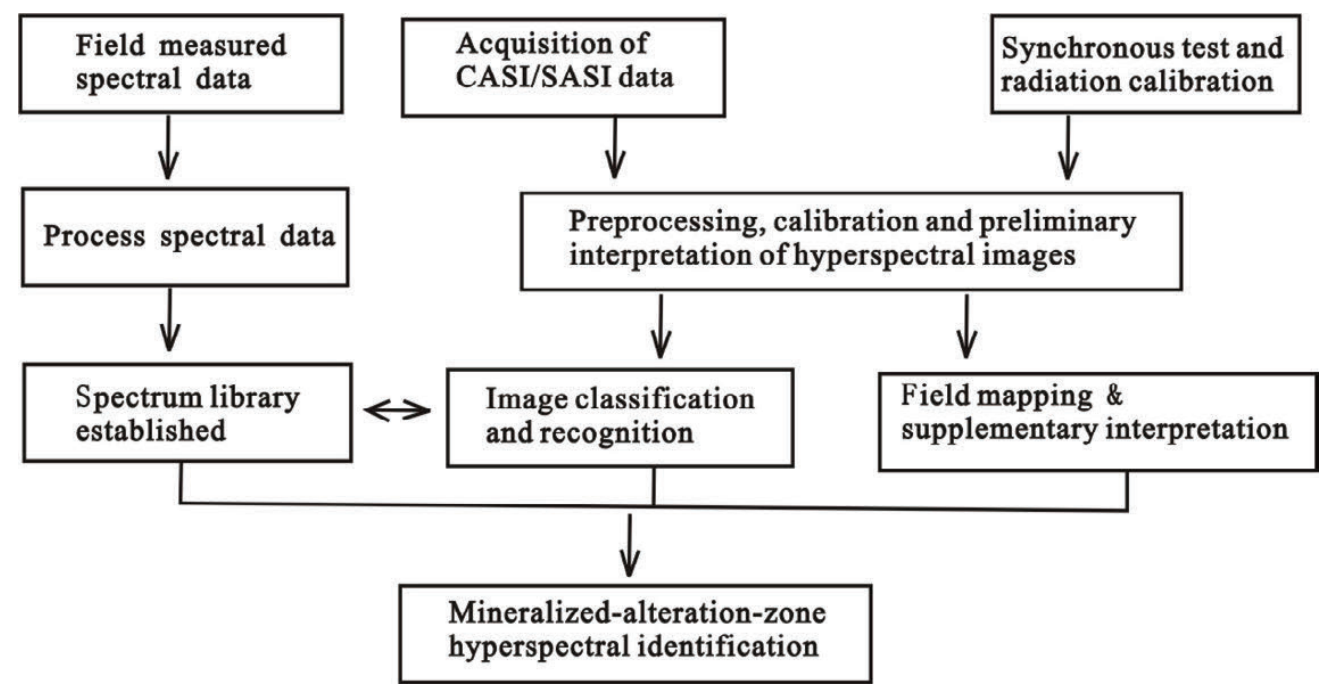

Figure 2. Technical flow chart.

ver, lead and zinc mines in coordination with ground synchronous testing and radiometric calibration. A FieldSpec ${ }^{\circledR}$ Pro FR portable spectrometer was used to obtain the spectral signatures of all types of samples for rock, ore deposits, and mineralizedalteration zones. And the main mineral spectrum library was established. Finally, hyperspectral-alteration mineral mapping of wall rock and hyperspectral identification of mineralized-alteration zones were performed in the study area, and their effects were verified by field investigation (Figure 2).

\subsection{Data acquisition}

The CASI/SASI data used in this study were acquired by the CASI/SASI/TASI Airborne Imaging Spectrometry System (AHIS) developed by ITRES Canada. CASI-1500 and SASII-600 sensors, the ICU central controller, and a series of precise geometric- and radiation-correction instruments (GPS equipment, POSAV310, ILS solar irradiance measurement instrument, threeaxis stabilized platform PAV30 and IMU inertial navigation system) constitute the VNIR-TIR aviation hyperspectral-measurement system. Two kinds of data, 380-1,050 nm (CASI) and 950-2450 nm (SASI), are provided. The total number of bands reaches 388 , and the spatial resolution reaches the sub-metre level. Three imaging modes are available: spatial, spectral, and full-frame. The main technical indicators are listed in Table 1. The system is mainly used in mineral-resource exploration, environmental monitoring, disaster detection and management, and other fields, providing technical support for the development of quantitative remote-sensing technology in China (YANG et al., 2015).

On September 6, 2012, a Yun-5 small multi-purpose aircraft carrying a hyperspectral sensor was used to collect test data over the Huaniushan gold, silver, lead, and zinc mine in Gansu Province. The flight altitude was $1,500 \mathrm{~m}$. Two hyperspectral datasets were obtained from $10 \mathrm{~km}^{2}$ airstrips. The flight path is shown in Figure 1. (Coverage area of hyperspectral data). The weather was clear and cloudless on the day of data acquisition. Hyperspectral data included the CASI VNIR band and the SASI SWIR band. There were 36 bands of CASI data. The spectral-coverage range was $380-1,045 \mathrm{~nm}$, the spectral resolution was $18 \mathrm{~nm}$, and the spatial resolution was $1 \mathrm{~m}$. SASI data consist of 101 segments with a spectral coverage of 950-2450 nm, a spectral resolution of $15 \mathrm{~nm}$ and a spatial resolution of 2.25 metres. In the process of aerial flight survey, field spectral tests were carried out at the same point on the ground in the main mineralized area.

\subsection{Spectrum test}

Spectrum testing is based on the FieldSpec $\AA$ Pro FR portable spectrometer produced by the American ASD Company. It is suitable for remote-sensing measurement, crop monitoring, forest research, industrial-lighting surveys, oceanographic research, and mineral exploration. Wavelength range: $350-2500 \mathrm{~nm}$, detector: $350-1050 \mathrm{~nm}$, low noise 512 elements PDA, 1000-1800 nm and $1800-2500 \mathrm{~nm}$, two INGaAs detector units, PE refrigeration constant temperature.

The purpose of spectrum testing is to determine the absorption and reflection bands of the different rocks or minerals that correspond to each band of the hyperspectral remote-sensing image, and to find the absorption and reflection bands of different minerals or rocks. Typical rocks and minerals are extracted by methods of difference, ratio, principal component, and classification in different bands, and spectral inversion of typical rocks or minerals from high-resolution remote-sensing images is realized.

Survey points are laid out according to the survey method of the geological section. Profile measurements cross the main lithostratigraphic and mineralized-alteration zones and are collected according to at least one test sample per typical stratigraphic unit. Rock-test points on profiles should be encrypted according to lithological changes or testing of multiple samples at the same point, including typical lithology related to mineralization, rock in fractured zones, altered rocks, and hydrothermal

Table 1. Main technical parameters of the CASI/SASI airborne imaging spectrometer.

\begin{tabular}{lccccccc}
\hline Parameters & Spectral range & $\begin{array}{c}\text { Pixel number } \\
\text { per row }\end{array}$ & $\begin{array}{c}\text { Number of } \\
\text { spectral } \\
\text { channels }\end{array}$ & $\begin{array}{c}\text { Spectral } \\
\text { bandwidth }\end{array}$ & $\begin{array}{c}\text { Frame } \\
\text { frequency } \\
\text { (full band) }\end{array}$ & $\begin{array}{c}\text { Angle of field } /\left(^{\circ} \text { ) }\right. \\
\begin{array}{c}\text { Instantaneous } \\
\text { field of view } \\
\text { angle } /\left(^{\circ}\right)\end{array}\end{array} \begin{array}{c}\text { Absoise-signal } \\
\text { ratio(peak value) }\end{array}$ & $\begin{array}{c}\text { Absolute } \\
\text { radiation } \\
\text { accuracy } / \%\end{array}$ \\
\hline CASI-1500 & $380-1050 \mathrm{~nm}$ & 1470 & 288 & $2.3 \mathrm{~nm}$ & 14 & 40 & 0.028 \\
SASI-600 & $950-2450 \mathrm{~nm}$ & 640 & 100 & $15 \mathrm{~nm}$ & 100 & 40 & $<1100$ \\
\hline
\end{tabular}




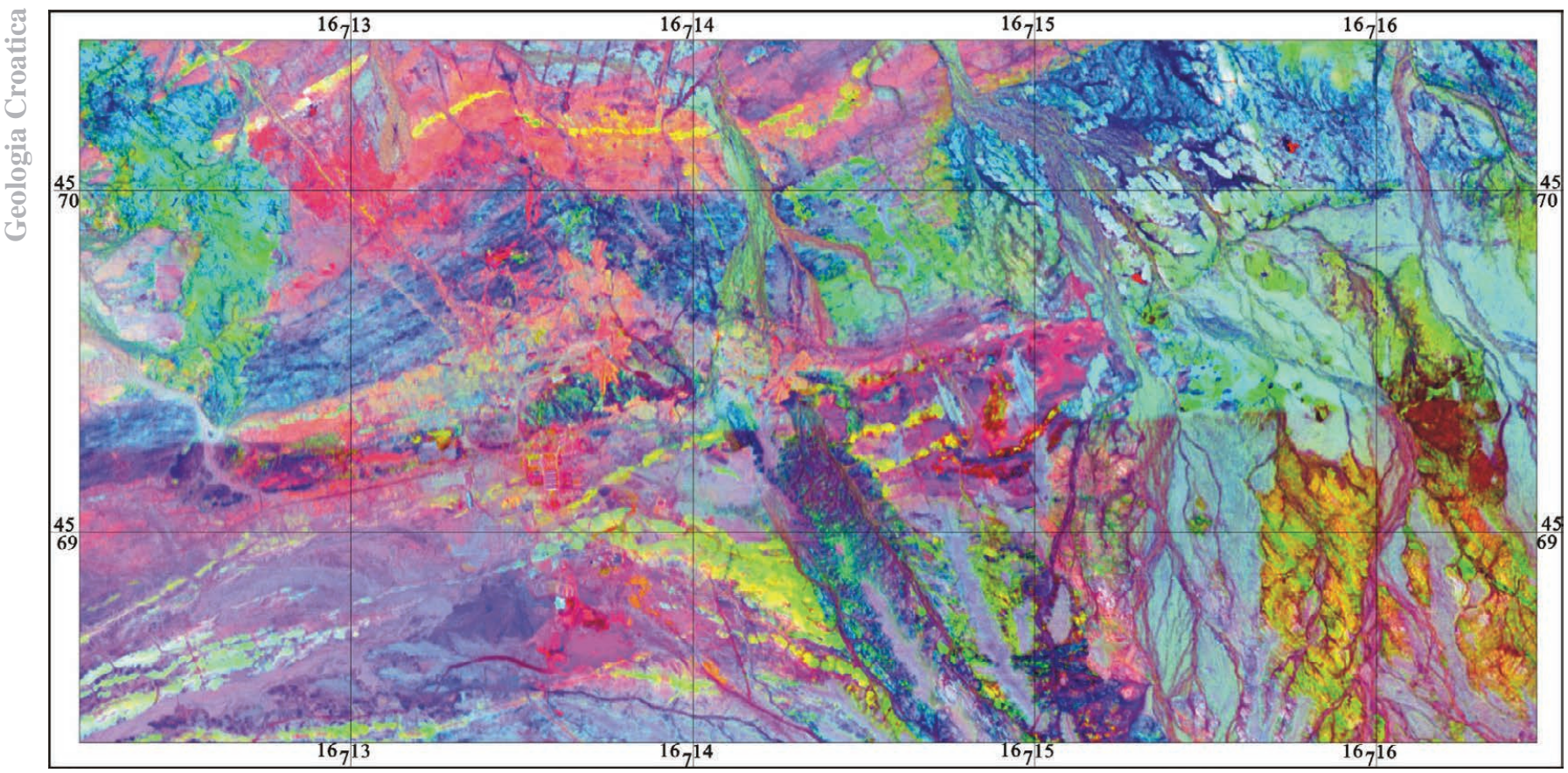

Figure 3. Hyperspectral remote-sensing image of the Huaniushan gold-silver-lead-zinc ore district (using airborne hyperspectral-image CASI/SASI data) (R:b25, G:b42, B:b87).

veins. The sample size is $3 \mathrm{~cm} \times 6 \mathrm{~cm} \times 9 \mathrm{~cm}$. GPS positioning is used for each sampling point, coordinate data are collected, field photographs are taken, and each typical rock sample measured is identified and retained in order to verify the accuracy of spectraltest results. At least one set of spectral curves was collected from each ore sample, and the parameters, such as the sample name, sample number, light-source type, test time, lens degree and distance from the sample, were recorded in detail.

Collect the spectral information of weathering surface and fresh surface of rock. Three samples were collected from different directions of weathering surface. Subsequently, the rock was cut and five samples were collected on the fresh rock surface.

The basic parameters of the characteristic-absorption peaks of minerals and water are as follows:

About $1400 \mathrm{~nm}$ : OH-absorption peak;

1900-2000 nm: water-absorption peak: high-temperature, high-crystallinity, good peak shape;

$2200 \mathrm{~nm}$ : AL-OH (kaolinite, muscovite, pyrophyllite);

2250-2300 nm: Fe-OH, Mg-OH (chlorite, biotite);

2300-2400 nm: carbonate, $\mathrm{Mg}-\mathrm{OH}$ (talc, tremolite).

The spectral data obtained in the field are processed and the relative abundances of minerals are determined by the ratio of the characteristic-absorption peaks of minerals to that of water. The results of the ratio calculation can be divided into six categories: absorption strength, integral strength, half width, reflectance, intensity ratio, and central wavelength. The higher the value, the higher the mineral abundance. Based on the results of rock and mineral analysis, the spectral curves of minerals corresponding to the standard spectral library were compared and analyzed, and the distribution regularity of ores' characteristic spectral bands was summarized.

\subsection{Data processing}

Because of the influence of flight-platform coordinates, flight attitude, the sun, the atmosphere, and other factors, the original remote-sensing image is distorted and there are errors in space. Thus, before extracting mineral-alteration information, CASI/SASI data should first be processed. CASI and SASI data (YE et al., 2011) processing include six main steps: data browsing, spatial resampling, band matching, geometric correction, atmospheric correction, and radiometric calibration (YE et al., 2011; SUN et al., 2015). After processing, the hyperspectral image is shown in Figure 3.

\subsubsection{Data browsing, removal of repetitive bands, selection of} bands

The hyperspectral data were checked and found to be duplicated between $950 \mathrm{~nm}$ and $1,047 \mathrm{~nm}$. The duplicated spectra in SASI were removed. Several bands near the 1,400 and 1,900-nm spectra (which correspond to atmospheric windows and are heavily affected by water and gas) increase the amount of data calculation and have no research value, so they were removed (Figure 4). After band removal, 92 hyperspectral bands remained.

\subsubsection{Spatial resampling}

Because of the inconsistent spatial resolution of the CASI/SASI data, spatial resampling is necessary. There are three common sampling methods: nearest, bilinear-interpolation, and cubic-convolution. For this study, the bilinear-interpolation method was chosen. The results obtained by this method are smoother and suitable for continuous data.

\subsubsection{CASI and SASI band matching}

The acquired CASI/SASI data are positioned 10 pixels $(2.25 \mathrm{~m} /$ pixel) differently in space. The method of selecting ground-control points is based on CASI data and the geometric correction of SASI data by a quadratic polynomial. Then, CASI and SASI band matching is carried out to generate hyperspectral data in the range of $368.7-2,450.0 \mathrm{~nm}$.

\subsubsection{Geometric correction}

The hyperspectral data has two spectral ranges, 380-1050nm and $950-2450 \mathrm{~nm}$. Firstly, preliminary geometric correction of the data is completed based on the data parameters of the system. Then, 


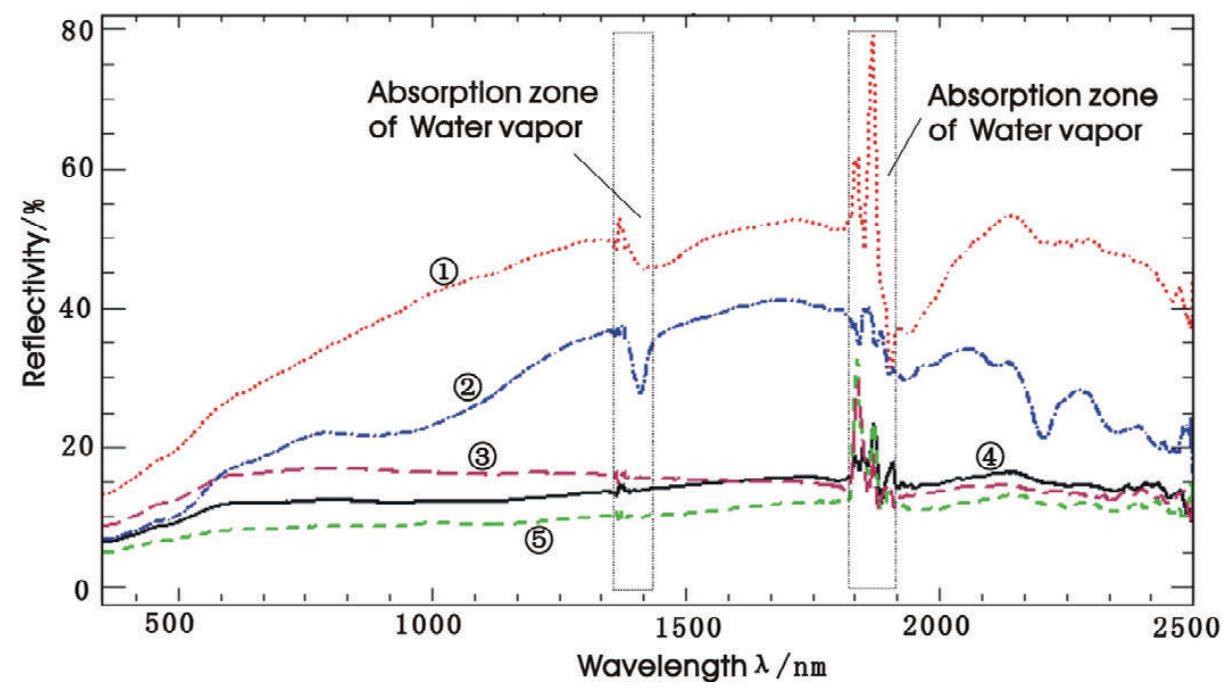

Figure 4. Field-spectral curve of rocks in the study area (1. marble, 2. granite porphyry, 3. skarn, 4. lamprophyre, 5. phyllite).

based on the collected basic geographic data and the measured control points, such points are selected and the hyperspectral data are geometrically corrected by quadratic polynomials. The selection of control points on maps (or on the spot) and images can clearly identify and precisely locate the obvious object points, which do not change with time. The number of control points in a ground measurement is large and the distribution is uniform.

\subsubsection{Image mosaic}

The results of the two-airstrip correction are a mosaic. An overlapping check is carried out before the mosaic, and the overlap tolerance between the airstrips meets the technical requirements. In the mosaic, the image with high resolution, new time, less cloud, and good quality should be preserved as far as possible. The mosaic line allows dislocation, blurring, duplication, and halos to be avoided.

\subsubsection{Radiation calibration}

In this paper, the spectral curves of marble, granite porphyry, skarn and lamprophyre vein measured in the field were compared with the spectral reconstruction results of image features. The correspondence between the two is $98 \%$, which meets the needs of this alteration information extraction.

\section{HYPERSPECTRAL REMOTE-SENSING CHARAC- TERISTICS OF THE GOLD, SILVER, LEAD, AND ZINC METALLOGENIC AREA IN HUANIUSHAN}

\subsection{Spectral-angle-mapping (SAM)}

Spectral-angle-mapping (SAM) is an automatic classification method, which compares the spectrum in the image with the spectrum in the spectral library, and determines their similarity by calculating the spectral angle between them.

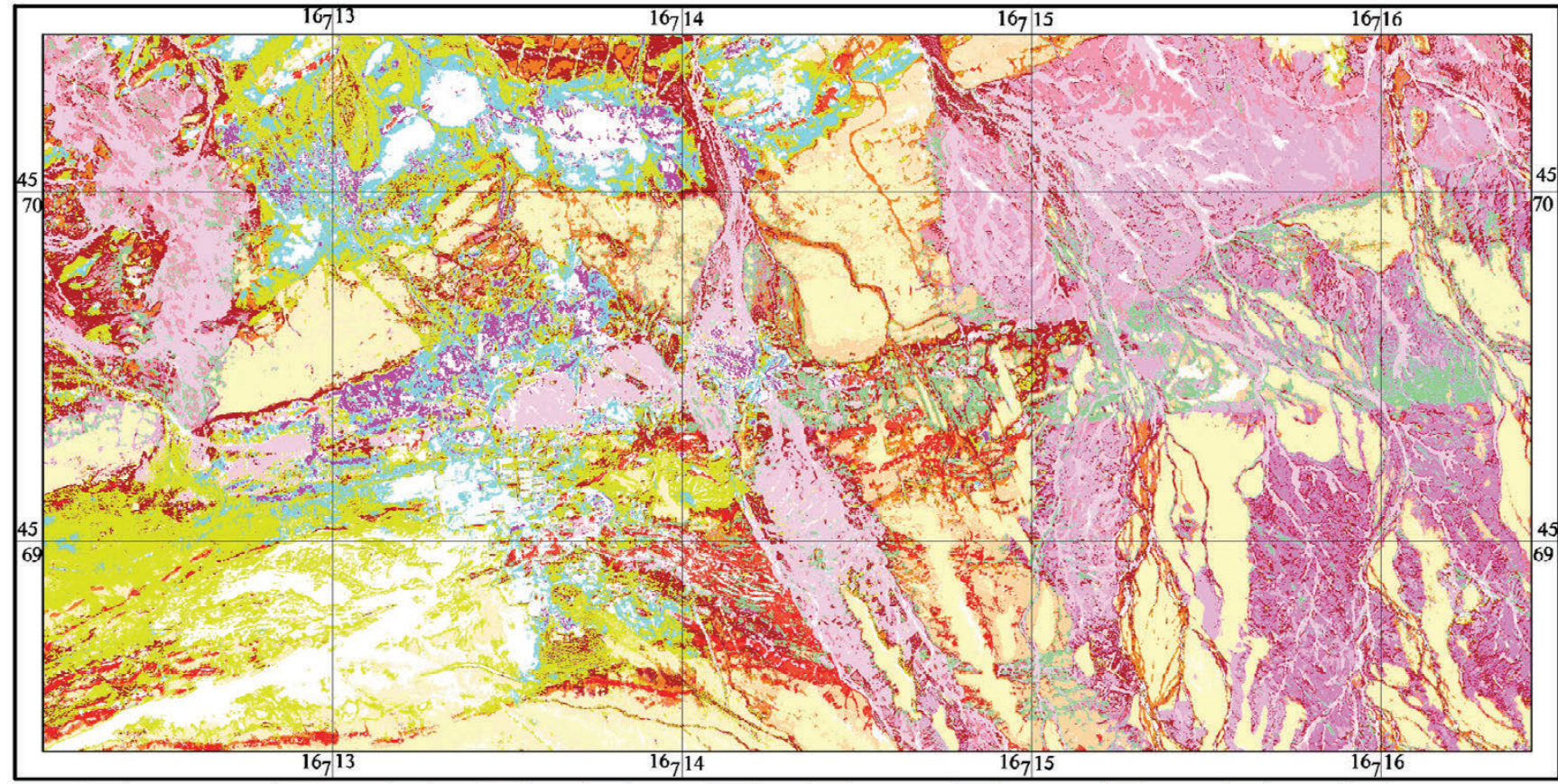

Legend $\square$ alluvial material $\square$ phyllite $\square$ schist $\square$ marble $\square$ hornstone $\square$ skarn $\square$ monzonite $1 \square$
granite-porphyry $\square$ plagioclase granile porphyry $\square$ lamprophyre

Figure 5. Geology classification figure of hyperspectral remote sensing in the study area. 
According to the spectral library established by the reflected spectral curve of each feature in the collected image, spectral curve reflected were divided into 15 categories, including: alluvial material, phyllite, schist, marble, hornstone, skarn, monzonite 1, monzonite 2, granite 1, granite 2, granodiorite, granite-porphyry, plagioclase granite porphyry, lamprophyre, mineralized alteration zone. At the same time, the typical features (vegetation, water, cloud, etc.) were also classified. The geological classification figure of hyperspectral remote sensing in the study area was obtained after classification and post-processing (Figure 5).

\subsection{Hyperspectral mapping of altered minerals in the surrounding rocks}

Under the influence of multi-stage magmatic intrusion and hydrothermal activity, the rocks in the Huaniushan gold-silver-leadzinc metallogenic area have undergone relatively strong hydrothermal alteration, resulting in sericitization, chloritization, silicification, muddification (kaolinite), carbonation (calcite, iron carbonate rock), skarnization (diopside, garnet, etc.), potash feldspar (jarosite) and other altered minerals (DAI, 2010, YANG et al., 2010). They are of great significance to the formation of gold, silver, lead, and zinc deposits in the study area. The depth of the absorption band is closely related to the content of these minerals in the rocks. The spectral characteristics of various types of altered mineral samples in the study area are shown in Figure 6.

According to the characteristic-absorption spectra of the altered minerals (reflectivity data $\rightarrow$ Minimum noise separation $(\mathrm{MNF}) \rightarrow$ PPI pixel purification $\rightarrow$ extracting end element training samples $\rightarrow$ Hyperspectral mapping of altered minerals in surrounding rock (SAM)), the mineral extraction method of hyperspectral remote sensing was used to extract and identify the altered minerals (LIN et al., 2011; WANG et al., 2010). Alteration minerals are mainly distributed in the marble section of the Pingtoushan Formation of the Jixian System, which is the main orebearing horizon in the area and intruded by the Indosinian granite body. In addition, there are dozens of granite porphyry and lamprophyre dykes interpenetrating and intruding the country strata. Marble has extensive contact with rock mass and strongwall rock alteration.

All 92 bands of the test data were transformed by MNF, and 20 bands with high eigenvalue were output. The pixel purity index (PPI) of these 20 bands was calculated. The number of iterations was 10000 and the noise threshold was 3. Through pixel purity index (PPI), the purest pixel in the data was extracted and the sample space was established. The unknown spectrum in the field measured spectrum library of altered minerals was matched with that in the standard spectrum library. A series of matching coefficients was obtained to determine the mineral types. Based on the characteristic absorption spectra of qualitative mineral types and the method of spectral angle classification (SAM), the distribution maps of various altered minerals in the study area were obtained (Figure 7).

\subsection{Hyperspectral recognition of the mineralized-alte- ration zone}

Ore bodies and veins in the Huaniushan Au-Ag-Pb-Zn metallogenic area are generally finer, and mostly more than ten centimetres in diameter?. The spectral curves of galena, sphalerite, and other ores are relatively straight, and there are no obvious characteristic-absorption bands. However, iron-oxide outcrops (limonite, haematite, jarosite) are a significant indicator of this type of mineralized surface (Plate 1). Chemical characteristics generally

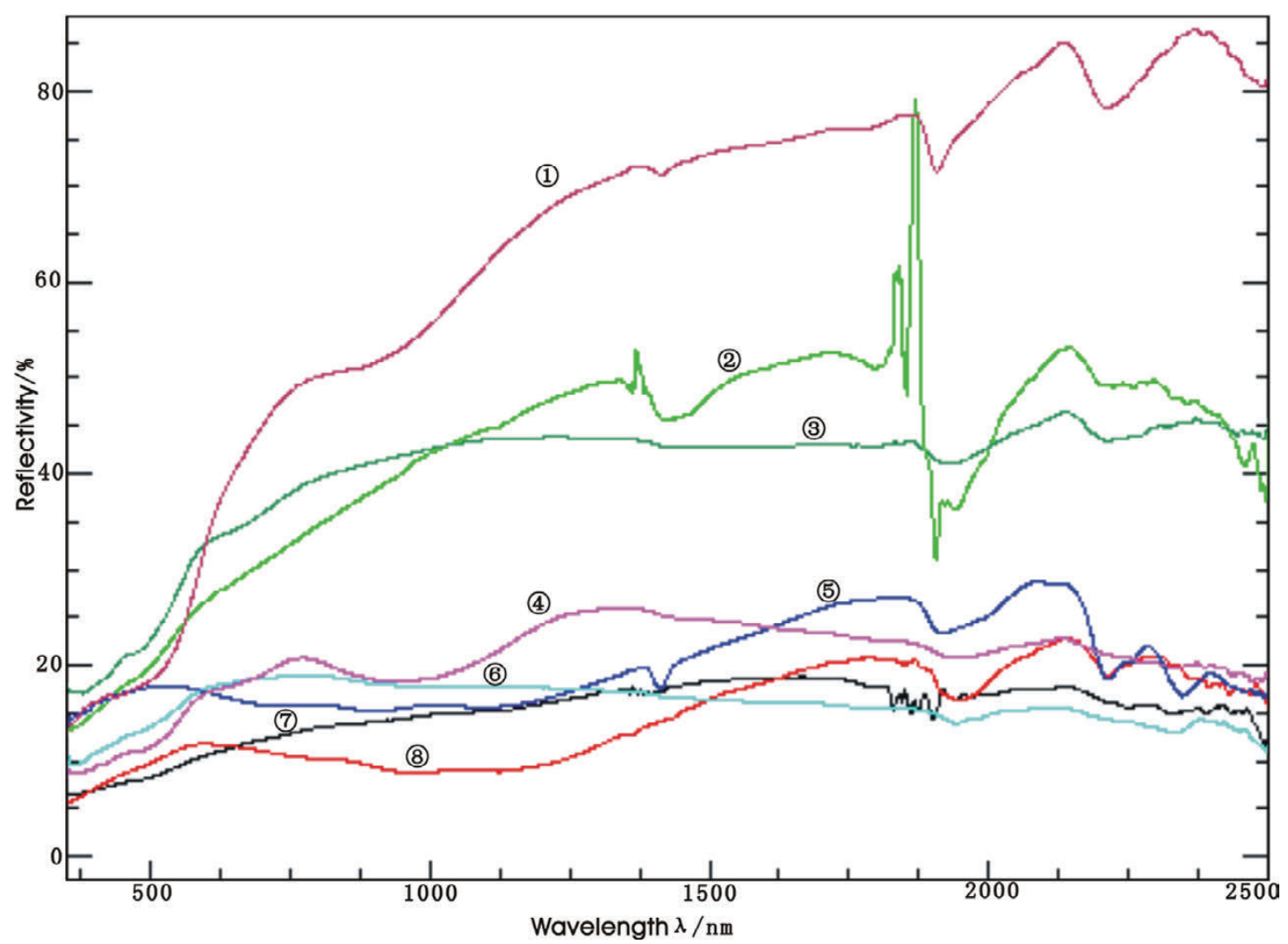

Figure 6. Spectral curves of all kinds of alteration minerals in the study area (1. kaolinite, 2. silicification, 3. K-feldsparization 4. Fe-carbonate rocks, 5. chloritization, 6. calcite, 7. sericite, 8. diopside). 


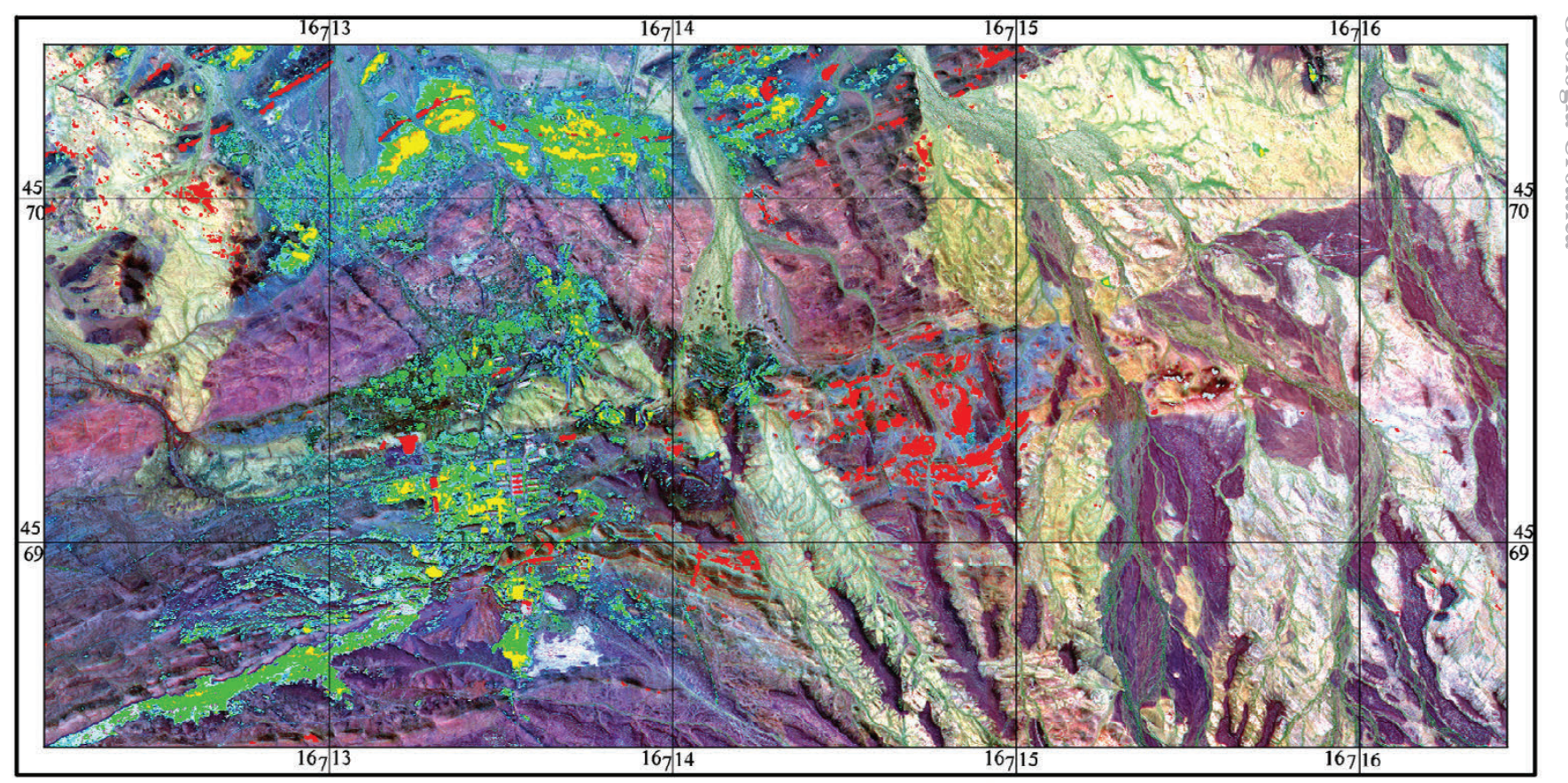

Legend $\square$ kaolinite $\square$ calcite $\square$ sericite $\square$ diopside $\square$ chlorite $\square$ silicification $\square$ jarosite $\square$ Fe-carbonate

Figure 7. Distributions of all kinds of alteration minerals in the study area (kaolinite, calcite, sericite, diopside, chlorite, silicification, jarosite, Fe-carbonate rocks).

contain $\mathrm{Fe}^{2+}, \mathrm{Fe}^{3+}$, and there are characteristic-absorption and strong-reflection bands in the visible band (GAN et al., 2003). These are easy to identify via remote-sensing images, which have a particular guiding significance for discovering gold, silver, lead and zinc ore bodies (veins) in the study area.

In order to locate the ore bodies and veins in the gold-silverlead-zinc metallogenic area of the study area, we used the method of looking for surface-iron oxides and field verification to confirm it. The spectral curves of several iron oxides were collected on the image, and each spectral curve was filtered by a mixed-modulation-matching filter. The average value of the filtered image shows that the metal cations of iron-oxide (jarosite) in the study area absorb strongly at $0.45 \mathrm{~m}, 0.55 \mathrm{~m}, 0.85 \mathrm{~m}, 0.90 \mathrm{~m}$, and $0.94 \mathrm{~m}$, have strong absorption bands between $0.9 \mathrm{~m}$ and $1.0 \mathrm{~m}$, and have relatively strong reflection between $0.6 \mathrm{~m}$ and $0.8 \mathrm{~m}$. Hydroxy anions absorb strongly between 2.2 and $2.3 \mathrm{~m}$ (Figure 8). Their characteristic-absorption bands and the corresponding bands of SASI images are shown in Table 2. Mixed-modulationmatched filtering is used to map iron-oxide minerals from the transformed images. The consistency between the ore vein extracted and the ore vein verified in the field were $85 \%$ (Figure 9). Therefore, the extraction effect was good, which was worthy of application and promotion.

\section{CONCLUSION}

On the basis of obtaining a large amount of geological data, airborne hyperspectral remote-sensing data (CASI/SASI) and field rock and mineral spectra of the Huaniushan gold-silver-lead-zinc mining area, spectral testing of rock, ore deposit and alteredmineralization zone samples was carried out through spectral testing and rock and mineral sampling analysis. Finally, hyper-

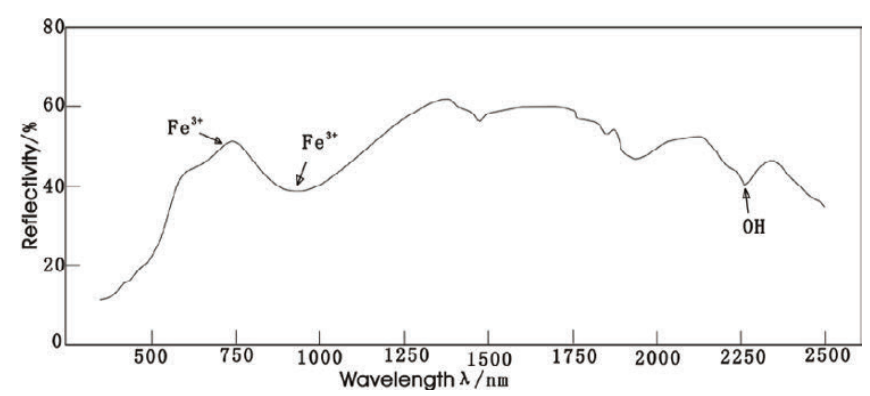

Figure 8. Spectral curve of jarosite in the study area (found).

spectral mapping of wall rock-altered minerals and hyperspectral identification of the altered-mineralization zone were performed in the study area. Combined with field investigation and verification, the following conclusions were obtained:

1) The alteration-mineral-information maps of the surrounding rocks in the study area show that the rocks in the Huaniushan gold-silver-lead-zinc metallogenic area have undergone relatively strong hydrothermal alteration due to the influence of multiple magmatic intrusions and hydrothermal activities. Alteration minerals are mainly distributed in the marble section of the Pingtoushan Formation of the Jixian System, mostly by sericitization, chloritization, silicification, muddification (kaolinite), carbonation (calcite, iron carbonate rock), skarnization (diopside, garnet, etc.), potassium feldspar (jarosite), etc. The distribution range of altered minerals is basically consistent with the results of field investigations, indicating that hyperspectral imaging can provide accurate and reliable information for prospecting.

2) The surfaces of ore bodies and veins in the Huaniushan gold-silver-lead-zinc metallogenic area are marked by iron-oxide

Table 2. Iron minerals' characteristic-absorption spectrum and the corresponding image band of CASI/SASI.

\begin{tabular}{lll}
\hline lons and Groups & Characteristic absorption spectra $/ \mu \mathrm{m}$ & Corresponding to SASI band \\
\hline $\mathrm{Fe}^{2+}, \mathrm{Fe}^{3+}$ & $\mathrm{Fe}^{2+}: 1.1-2.4 ;$ & b1-b6, b22-b26 \\
\hline
\end{tabular}




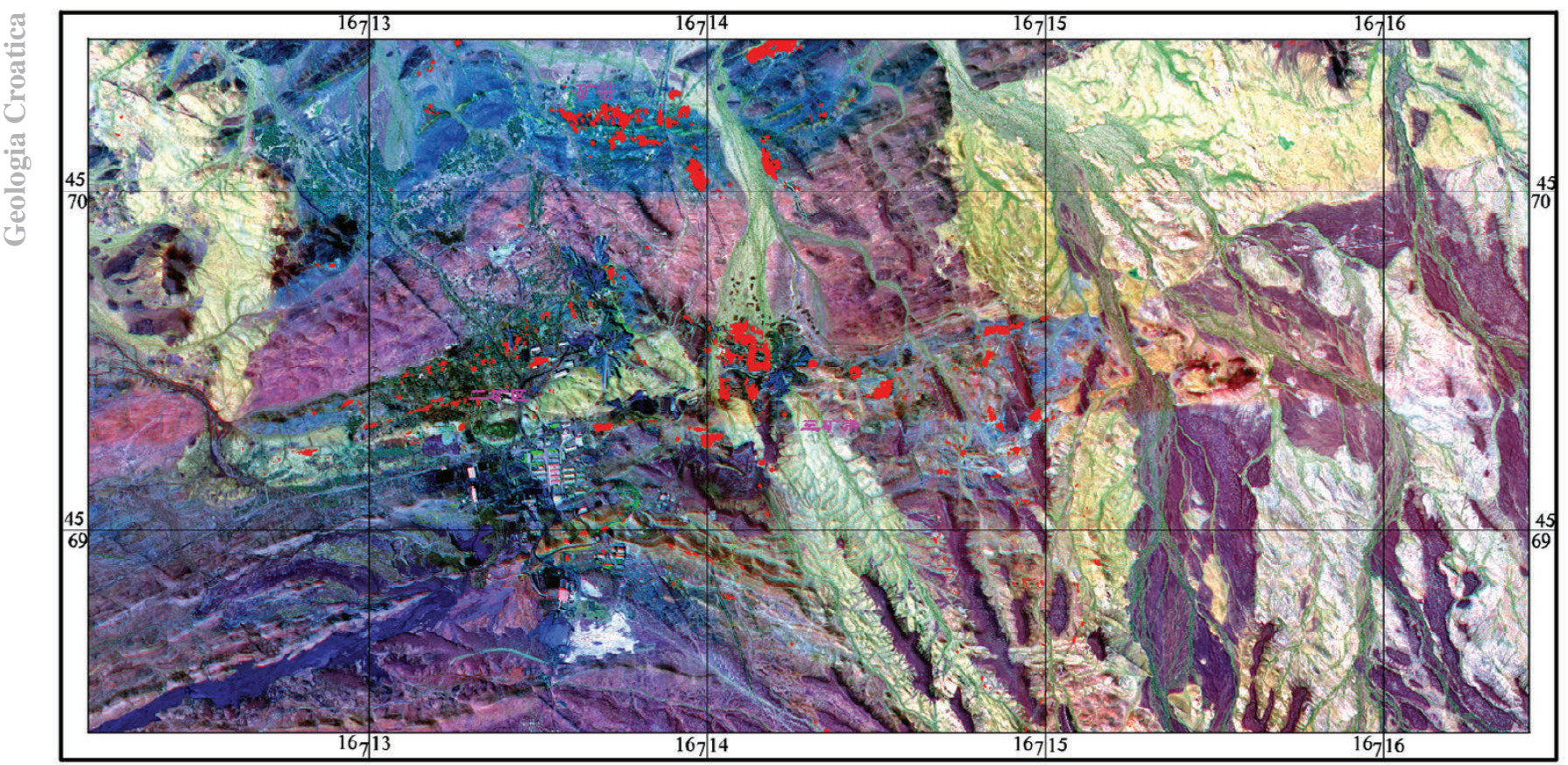

mineralization alteration zone

Figure 9. Distribution of mineralized-alteration zones distribution in the study area.

outcrops (limonite, hematite, jarosite). The mixed-modulationmatched-filtering method is used to identify and extract the mineralized alteration zone containing $\mathrm{Fe}^{2+}, \mathrm{Fe}^{3+}$. The results of extraction basically agree with the field-verification results, which have a certain guiding significance for finding gold, silver, lead, and zinc ore bodies (veins) in the study area.

3) This paper indicates that airborne hyperspectral-remotesensing-image CASI/SASI data offer good application results and show promising potential in geological exploration. Our results will provide the basis for hyperspectral remote-sensing prospecting in the same or similar unexplored areas.

\section{ACKNOWLEDGEMENT}

This research was financially supported by China Geological Survey Project (No. 12120113073000; No.DD20160117) and National key basic research program of "973" project(2015CB453000). Thanks to the anonymous reviewers and editors of Tea FLUKSI, Lidija GALOVIĆ, and Julie ROBSON for their suggestions on the paper.

\section{REFERENCES}

ALIJAGIĆ, J. \& ŠAJN, R. (2020): Application and improvement of soil spatial distribution mapping using advanced modelling techniques.- Geologia Croatica, 73/1, 69-84. doi: $10.4154 /$ gc. 2020.01

BANDFIEL, D. (2002): Globe mineral distribution on Mars.- Geophysical Res., 107 (E6), 5024

BISHOP, C.A., LIU, J.G. \& MASON, P.J. (2011): Hyperspectral remote sensing for mineral exploration in Pulang, Yunnan Province, China.- International Journal of Remote Sensing, 32, 2409-2426. doi: 10.1080/01431161003698336

BRONGE, L.B. \& NASLUND, L.B. (2002): Wetland classification for Swedish CORINE land cover adopting a semi-automatic interactive approach.- Canadian Jounral of Remote Sensing, 28/2, 139-155.

CAO, L., SHAN, L. \& ZHANG, Y.L. (2008): Metallogenetic types of Lead-Zinc deposit and prospecting direction in Beishan area.- Resources Environment \& Engineering, 22/1, 26-31. (in Chinese with English abstract).

CHEN, F., JIANG, A., TANG, P., YANG, R. \& ZHOU, W. (2017): Multi-scale synthetic aperture radar remote sensing for archaeological prospection in Han Hangu Pass, Xin'an China.- Remote Sensing Letters, 8, 38-47. doi: 10.1080/2150704X. 2016.1235812
CLARK, R.N., KING, T.V.V., KLEJWA, M., SWAYZE, G.A. \& VERGO, N. (1990): High Spectral Resolution Reflectance Spectroscopy of Minerals.- J. Geophys. Res., 95, 12653-12680. doi: 10.1029/JB095iB08p12653

CLARK, R.N., SWAYZE, G.A., LIVO, K.E., KOKAL,Y.R.F., SUTLEY, S.J., DALTON, J.B., MCDOUGAL, R.R. \& GENT, G.A. (2003): Imaging spectroscopy: Earth and planetary remote sensing with the USGS Tetracorder and expert systems.- Jourmal of Geophysical Research, 108/E12, 1-44. doi:10.1029/2002.JE001847

CLOUDS, E.A. (1996): Hyperspectral geological remote sensing: evaluation of analytical techniques.- Int. J. Remote Sensing, 17/12, 2215-2242.

DAI, W.J. (2010): Metallogenic Study of Huaniushan Au-Ag-Pb-Zn Deposit, Beishan area, Gansu Province.- Geology and Mineral Resources of South China, 3, 25-33. (in Chinese with English abstract).

DRAKE, N.A. (1995): Reflectance spectra of evaporite minerals (400-2500 nm): applications of remote sensing.- Int. J. Remote Sensing, 16/14, 2555-2571. doi: $10.1080 / 01431169508954576$

EVERITT, J.D., ESCOBAR, D.E., GERBERMANN, A.H. \& ALANIZl, M.A. (1988): Detecting saline soils with video imagery.- Photogramm. Eng. Remote Sensing, $54,1283-1287$

FAN, Y., WANG, H., YANG, X., LIANG, M., PAN, C., ZHANG, S., WANG, W. \& TAN, F. (2021): Application of high resolution remote sensing technology for the iron ore deposits of the West Kunlun mountains in China.- Geologia Croatica, 74/1, 57-72. doi: 10.4154/gc.2021.03

GAN, F.P., WANG, R.S., GUO, X.F. \& WANG, Q.H. (2000): Extraction for rock and ore deposits information and prospects for application of geology using hypersperctral remote sensing - Tibet plateau as test sample.- Remote sensing for land \& resources, 12/3, 38-44. (in Chinese with English abstract).

GAN, F.P. \& WANG, R.S. (2007): The application of the hyperspectral maging technique to geological investigation.- Remote sensing for land \& resources, 74/4, 57-60. (in Chinese with English abstract).

GAN, F.P., WANG, R.S., MA, A.N. \& ZHANG, Z.G. (2003): A iteration extracting based on spectral match filter (SMF).- Journal of image and graphics, 8/2, 147-150. (in Chinese with English abstract).

GONG, M.T. \& FENG, P.L. (2014): Preliminary study on the application of hyperspectral imaging in the classification of and identification Chinese traditional pigments classification - a case study of spectral angle mapper-- Sciences of conservation and archaeology, 26/4, 76-83. (in Chinese with English abstract).

GUO, J., CHANG, X., GAO, Y., SUN, X., SUN, G. \& HUANG, C. (2009): Lake Level Variations Monitored With Satellite Altimetry Waveform Retracking.- IEEE Journal of Selected Topics In Applied Earth Observations and Remote Sensing, 2, 80-86. doi: 10.1109/JSTARS.2009.2021673

GUO, N., GUO, K., ZHANG, T.T., LIU, T.H., HU, B. \& WANG, C.W. (2012): Hydrothermal alteration distribution model of the Jiama (Gyama) Copper-Polymetallic deposit based on Shortwave Technique.-Acta Geoscientica Sinica, 33/4, 641-653. (in Chinese with English abstract). doi: 10.3975/cagsb.2012.04.24 
HE, Z.Z., CAO, J. \& DONG, Q.W. (2012): Geological characteristics of the gold deposits and prospecting idea at the East Huaniushan in Gansu Beishan.- Gan Su Metallurgy, 34/3, 74-78. (in Chinese with English abstract).

HOWARI, F.M., AYDAROOS, F.A., NAZZAL, Y., IQBAL, J. \& BOU ORM, N. (2019): Hyperspectroscopic and microtopographic analysesof salt crust forms on arid, silty clay loam desert soils.- Geologia Croatica., 72/1, 43-49. doi: 10.4154/gc.2019.01

HU, P., TIAN, Q.J. \& YAN, B.K. (2009): The application of hyperspectral remote sensing to the identification of hydrocarbon alteration minerals in Qaidam Basin.- Remote Sensing for Land \& Resources, 80/2, 54-61. (in Chinese with English abstract).

HU, Q., MA, R., CHEN, F., JIANG, A. \& WANG, Y. (2018): Urban landscape monitoring based on high-resolution spaceborne TerraSAR-X data: a case study of Nanjing City, China.-Remote Sensing Letters, 9, 448-457. doi: 10.1080/2150704X.2018.1437289

HUNT, G.R. (1989): Spectroscopic Properties of Rocks and Minerals.- In: CARMICHEL, R.C.: Practical Handbook of Physical Properties of Rocks and Minerals, CRC Press Inc, Boca Raton, Florida, 599-669.

JIANG, A., CHEN, F., LIU, G. \& TANG, P. (2018): Use of instantaneous GPR attribute integration in prospecting for ancient roads at the Han Hangu Pass, Xin'an, China.Remote Sensing Letters, 9, 429-437. doi: 10.1080/2150704X.2018.1433342

KOKAL, Y. R.F., CLARK, R.N. \& LIVO, K.E. (1998): Mapping the Biology and Mineralogy of Yellowstone National Park using Imaging Spectroscopy.- Summaries of the 7th Annual JPL Airborne Earth Science Workshop, R.O. Green, Ed, AVIRIS Workshop, JPL Publication, 97-21/1, 245-254.

KRUSC, F.A. (2012): Mapping surface mineralogy using imaging spectrometry.- Geomorphology, 137/1, 41-56. doi: 10. 1016/j.geomorph. 2010.09.032

KRUSE, F.A., KIEREIN, Y.S. \& BOARDMAN, J.W. (1990): Mineral mapping at Cuprite, Nevada with a 63-channel imaging spectrometer-- Photogrammetric Engineering \& Remote Sensing, 56/1, 83-92.

LAPOTRE, M.G.A., EHLMANN, B.L. \& MINSON, S.E.A. (2017): Probabilistic approach to remote compositional analysis of planetary surfaces.- Journal of Geophysical Research: Planets, 122, 983-1009. doi: 10.1002/2016JE005248

LI, J., HAN, J.C., ZHANG, Y. \& CHENG, K. (2014): Research progress on hyperspectral remote sensing technology in monitoring crop nutrition.- Modern Agricultural Science and Technology, 24, 251-254. (in Chinese with English abstract).

LI, M.Z. \& ZHANG, P.Y. (2015): Classification of wetland vegetation in hyperspectral remote sensing image based on SAM algorithm.- Forest engineering, 31/2, 8-13. (in Chinese with English abstract).

LIN, N., YANG, W.N. \& LIU, H.H. (2011): Mineral endmember identification and information extraction based on hyperspectral remote sensing.- Remote sensing information, 5, 114-117. (in Chinese with English abstract). doi: 10. 3969/j. issn.1000-3177.2011.05.021

LIU, D.C., XIE, H.J., LI, J.F., ZHAO, Y.J. \& HUANG, S.T. (1999): Hyperspectral data processing and research on geological application in Miao Er Shan district, Guangxi Province.- Remote sensing for land \& resources, 41/3, 65-71. (in Chinese with English abstract).

LIU, H., ZHU, H. \& WANG, P. (2017): Quantitative modelling for leaf nitrogen content of winter wheat using UAV-based hyperspectral data.- International Journal of Remote Sensing, 38, 2117-2134. doi: 10.1080/01431161.2016.1253899

LIU, K., ZHAO, D., FANG, J., ZHANG, X. \& ZHANG, Q. (2017): Estimation of Heavy-Metal Contamination in Soil Using Remote Sensing Spectroscopy and a Statistical Approach.- Journal of The Indian Society of Remote Sensing, 45, 805-813. doi: 10.1007/s12524-016-0648-4

LIU, L.J., PANG, Y., FAN, W.Y., LI, Z.Y. \& LI, M.Z. (2011): Integration of airborne hyperspectral CASI and SASI Data for tree species mapping in the Boreal Forest, China.- Remote Sensing Technology and Application, 26/2, 131-136. (in Chinese with English abstract)

MING, Y., CHENG, L., YU, H. \& WANG, C. (2018): Quantitative Inversion of Vegetation Biochemical Components Based on HJ1-A HSI in Coal Mining Area.- Journal of The Indian Society of Remote Sensing, 46, 69-79. doi: 10.1007/s12524017-0682-x

NIE, F.J., JIANG, S.H., BAI, D.M., WANG, X.L., SU, X.X., LI, J. C., LIU, Y. \& ZHAO, S. M. (2002): Metallogenic studies and ore prospecting in conjunction area of Inner Mongolia Autonomous Region, Gansu Province and Xinjiang Uygur Autonomous Region (Beishan Mt.), Northwest China.- Beijing: Geological Publishing House:1-34. (in Chinese).

PIETERS, C.M. \& MUSTARD, J.F. (1988): Exploration of crustal/mantle material for the earth and moon using reflectance spectroscopy.- Remote sensing of Environment, 24, 151-178. doi: 10.1016/0034-4257(88)90010-7

POUR, A.B., HASHIM, M. \& VAN GENDEREN, J.L. (2013): Detection of hydrothermal alteration zones in a tropical region using satellite remote sensing data: Bau goldfield, Sarawak, Malaysia.-Ore Geology Reviews, 54, 181-196. doi: 10.1016/j. oregeorev.2013.03.010

PU, R.L. \& GONG, P. (2000): Hyperspectral remote sensing and its application.- Beijing: Higher Education Press, 1-100. (in Chinese).

SCHAEPMAN, M.E., USTIN, S.L., PLAZA, A.J., OAINTER, T.H., VERRELST, J. \& LIANG, S.L. (2009): Earth system science related imaging spectroscopy - an assessment.- Remote Sensing of Environment, 113 (Supplement 1), S123-S137. doi: 10.1016/j.rse. 2009. 03. 001

SHI, Z., LI, P., JIN, H., TIAN, Y. \& CHEN, Y. (2017): Improving Super-Resolution Mapping by Combining Multiple Realizations Obtained Using the Indicator-Geostatistics Based Method.- Remote Sensing, 9/8, 773. doi: 10.3390/rs9080773

SUN, Y., ZHAO, Y.J., LI, H.B., LU, D.H., TIAN, F., QIN, K., YANG, G.F., ZHOU, J.J. \& LIU, P.F. (2015): HySpex hyperspectral mineral mapping of asiha gold ore district in Dulan County, Qinghai Province and its prospecting implications.- Acta Geologica Sinica, 89/1, 195-203. (in Chinese with English abstract).

SUN, Z., WANG, C., GUO, H. \& SHANG, R. (2017): A Modified Normalized Difference Impervious Surface Index (MNDISI) for Automatic Urban Mapping from Landsat Imagery.- Remote Sensing, 9/9, 942. doi: 10.3390/rs9090942

TANG, P.K., LI, Y.L., LI, G.B. \& YAN, B.K. (2006): Imaging spectrometry remote sensing technology and its applications in geology.- Mineral Resources and Geology, 20/2, 160-165. (in Chinese with English abstract). doi: 10.3696/j. issn.1001-5663.2006.02.013

TONG, Q.X., ZHANG, B. \& ZHENG, L.F. (2006): Multidisciplinary applications of hyperspectral remote sensing.- Beijing: Electronic Industry Press: 1-54. (in Chinese).

TRENC, N., MORGAN, K.T, M.M., DONOVAN, R.N. \& BUSBEY, A.B. (1999): Remote sensing analysis of selected terrestrial impact craters and a suspected impact structure in South Korea using space shuttle photographs.- Geologia Croatica, $52 / 2,203-215$.

VAN DER MEER, F.D., VAN DER WERFF, H.M.A., VAN RUITENBEEK, F.J. A.,HECKER, C.A., BAKKER, W.H., NOOMEN, M.F., VAN DER MEIJDE, M., CARRANZA, J.M., DE SMETH, B. \& WOLDAI, T. (2012): Multi-and Hyperspectral geologic remote sensing: A Review.- International Journal of Applied Earth Observation and Geoinformation, 14/1, 112-128. doi: 10.1016/j. jag.2011.08.002.

WAN, Y.Q., ZHANG, F.L. \& YAN, Y.Z. (2011): The analysis of mineral and Rock's hyper-spectral library.- Geo-information science, 3, 54-58. (in Chinese with English abstract).

WAN, Y.Q., ZHANG, F.L. \& YAN, Y.Z. (2003): The application of the hyperspectral remote sensing technology to water environment monitoring.- Remote sensing for land \& resources, 14/3, 10-14. (in Chinese with English abstract).

WANG, Q.H., WANG, R.S. \& GUO, X.F. (2000): Application for discrimination of rock using hyperspectral remote sensing technique.- Remote sensing for land \& resources, 46/4, 39-43. (in Chinese with English abstract).

WANG, R.S., GAN, F.P., YAN, B.K., YANG, S.M. \& WANG, Q.H. (2010): Hyperspectral minera1 mapping and its application.- Remote sensing for land \& resources, 83/1, 1-13. (in Chinese with English abstract).

WANG, J. \& OGAWA, S. (2017): Analysis of dynamic changes in land use based on landscape metrics in Nagasaki, Japan.- Journal of Applied Remote Sensing, 11/1, 016022. doi: 10.1117/1.JRS.11.016022

WANG, R., HU, Y., WU, H. \& WANG, J. (2016): Automatic extraction of building boundaries using aerial LiDAR data.- Journal of Applied Remote Sensing. 10/1, 016022. doi: $10.1117 / 1$.JRS. 10.016022

WANG, X.C., TIAN, Q.J. \& GUAN, Z. (2007): The extraction of oil and gas information by using Hyperion imagery in the Sebei gas field.- Remote Sensing for Land \& Resources, 71/1, 36-40. (in Chinese with English abstract).

WANG, Z., YU, S., TAO, Q., LIU, G. \& HAO, H. (2018): A method of monitoring three-dimensional ground displacement in mining areas by integrating multiple InSAR methods.- International Journal of Remote Sensing, 39/4, 1199-1219. Doi: 10.1080/01431161.2017.1399473

WEI, J., MING, Y., JIA, Q. \& YANG, D. (2017): Simple mineral mapping algorithm based on multitype spectral diagnostic absorption features: a case study at Cuprite, Nevada.- Journal of Applied Remote Sensing, 11/2, 026015. doi: 10.1117/1.JRS.11.026015

WEI, J. \& SUN, L. (2017): Comparison and Evaluation of Different MODIS Aerosol Optical Depth Products Over the Beijing-Tianjin-Hebei Region in China.- IEEE Journal of Selected Topics In Applied Earth Observations and Remote Sensing, 10/3, 835-844. doi: 10.1109/JSTARS.2016.2595624

XI'AN INSTITUTE OF GEOLOGY AND MINERAL RESOURCES (2006): The Prospecting Potential of Mineral Resources in Northwest China.- Beijing: Geological Publishing House, 1-150. (in Chinese).

XIANG, A.Q., LIANG, J., CHU, N., WANG, R.J., LU, Y. \& LIU, B.H. (2015): Airborne hyper-spectral mineral mapping and prospecting prediction in the Kalatage area, Xinjiang.- Mineral Exploration, 6/5, 586-593. (in Chinese with English abstract)

XIE, Q., MENG, Q., ZHANG, L., WANG, C. \& SUN, Y. (2017): A Soil Moisture Retrieval Method Based on Typical Polarization Decomposition Techniques for a Maize Field from Full-Polarization Radarsat-2 Data.- Remote Sensing. 9/2, 168. doi: 10.3390/rs9020168

XIE, Q., XU, F., WANG, N. \& YANG, Z. (2020): Geological conditions and gasbearing evaluation of the Niutitang Formation shale in the Xixiang-Zhenba area, China.- Geologia Croatica, 73/1, 49-58. doi: 10.4154/gc.2020.05

YAN, S.X., ZHANG, B., ZHAO, Y.C., ZHENG, L.F., TONG, Q.X. \& YANG, K. (2004): Summarizing the technical flow and main approaches for discrinination and map- 
ping of rocks and minerals using hyperspectral remote Sensing.- Remote sensing for land \& resources, 19/1, 52-63. (in Chinese with English abstract).

YANG, J.G., ZHAI, J.Y., YANG, H.W., WANG, X.H., XIE, C.L., WANG, X.A. \& REN, B.C. (2010): Metallotectonics and prospection of the Huaniushan exhalogene Gold-Silver-Lead-Zinc deposit in beishan, gansu Province-- Geotectonicaet Metallogenia, 34/2, 246-254. (in Chinese with English abstract).

YANG, Q.H., WU, X.J., XIAO, Z.H., LIU, X.J. \& DONG, M.X. (2015): Technology research on mineral extraction by using CASI/SASI airborne hyperspectral data.- Journal of Geomechanics, 21/2, 241-251. (in Chinese with English abstract).

YE, F.W., LIU, D.C. \& ZHAO, Y.J. (2011): Airborne hyper-spectral survey system CASI/SASI and its preliminary application in uranium exploration.- World Nuclear Geoscience, 28/4, 231-236. (in Chinese with English abstract). doi: 10.3969/j.issn.1672-0636.2011.04.008

YESSY, A., MIYATAKE, S., MOMOSE, A., ANNA, N., KOMBADAYEDU, M., APHARY, M., MINSOZI, S. \& EWERETH, M. (2011): Hyperspectral mapping for rock and alteration mineral with spectral angle mapping and neural network classification method: Study case in Warm bad district, south of Namibia.- Geoscience and Remote Sensing Symposium (IGARSS), IEEE, lnternational, 1752-1754.

ZHANG, Y.J., YANG, J.M. \& YAO, F.J. (2007): The potential of multi-spectrel remote sensing techniques for mineral exploration-taking the Mongolian Oyu Tolgoi Co-Au deposit as an example.- Earth Science Frontiers, 14/5, 63-70. (in Chinese with English abstract).
ZHANG, Z.C., ZHANG, X.J., HU, D.G., GAO, W.L. (2011): Application of hyperspectral remote sensing on mineral exploration in Dongdatan district of East Kunlun,Qinghai Province.- Geoscience, 25/4, 760-767. (in Chinese with English abstract).

ZHAO, S.-H., ZHANG, F., WANG, Q., YAO, Y.-J., WANG, Z.-T. \& YOU, D.-A. (2013): Application of hyper-spectral remote sensing technology in environmental protection. - Spectroscopy and Spectral Analysis, 33/12, 3343-3348. (in Chinese with English abstract). doi: 10.3964/j.issn.1000-0593(2013)12-3343-06).

ZHAO, X., WANG, P., CHEN, C., JIANG, T., YU, Z. \& GUO, B. ((2017): Water body information extraction from remote-sensing images after disasters based on spectral information and characteristic knowledge.- International Journal of Remote Sensing, 38/5, 1404-1422. doi: 10.1080/01431161.2016.1278284

ZHONG, S., XU, C., YI, L. \& LI, Y. (2018): Focal Mechanisms of the 2016 Central Italy Earthquake Sequence Inferred from High-Rate GPS and Broadband Seismic Waveforms.- Remote Sensing, 10/4, 512. doi: 10.3390/rs 10040512

ZHOU, Z.Y. (2014): Progress in hyperspectral remote sensing for petroleum prospecting.- Remote Sensing Technology and Application, 29/2, 252-261. (in Chinese with English abstract). doi: 10.11873/j.issn.1004-0323.2014.2.0352

ZHOU, W., PENG, B., SHI, J., SHI, J., WANG, T., DHITAL, Y.P., YAO, R., YU, Y., LEI, Z. \& ZHAO, R. (2017): Estimating High Resolution Daily Air Temperature Based on Remote Sensing Products and Climate Reanalysis Datasets over Glacierized Basins: A Case Study in the Langtang Valley, Nepal.- Remote Sensing. 9/9, 959. doi: 10.3390/rs9090959 

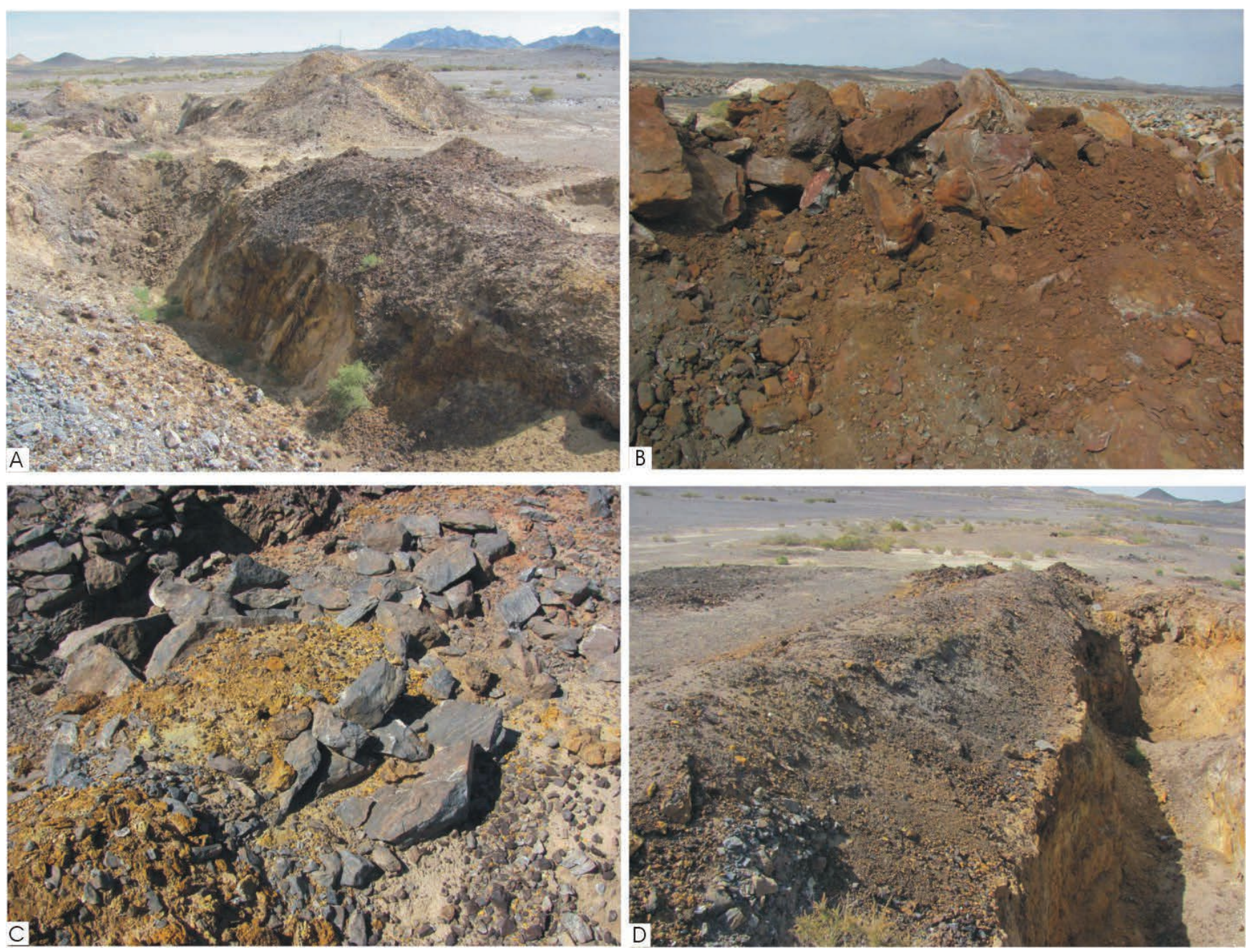

Plate 1. Iron- oxide outcrop of mineralized-alteration zones in the study area.

A - limonite;

B - hematite;

C - jarosite and

D - jarosite. 